
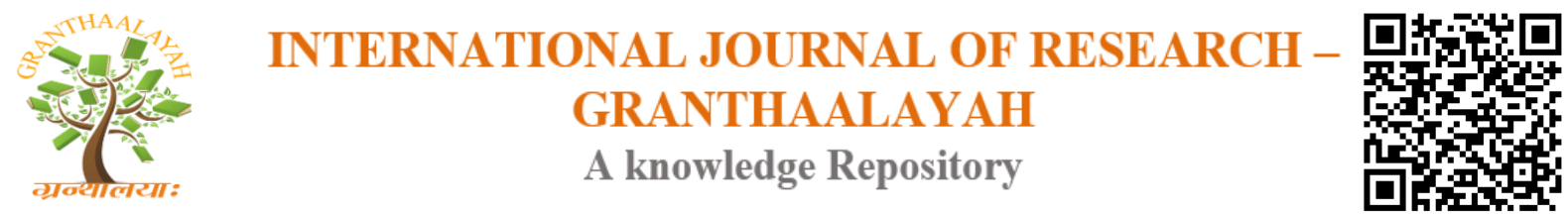

Social

\title{
EFFACING THE TAG OF FUNDAMENTALISM: A READING OF MOSHIN HAMID'S THE RELUCTANT FUNDAMENTALIST
}

\author{
Dr J G Duresh *1 \\ ${ }^{* 1}$ Associate Prof and Head Dept of English \& Centre for Research Scott Christian College \\ (Autonomous) Nagercoil, India
}

\begin{abstract}
The Paper entitled "Effacing the Tag of Fundamentalism: A Reading of Moshin Hamid's The Reluctant Fundamentalist" attempts to study Moshin Hamid's strenuous efforts to wipe out the image attached to his native land Pakistan as a Fundamentalist Country. The writer vociferously asserts that Pakistan is not as bad as the International community believes. Inorder to drive home his notion he recollects the experiences of Changez, a Pakistani youngster pursuing higher studies in America. The author tactfully depicts the changing attitude of America against the backdrop of September 11 attack on America. The author gloats over the glorious past of Pakistan, registers its present conflicts and envisages its glorious future.
\end{abstract}

Keywords: Migrants; Diaspora; Fundamentalism; Acculturation; National Consciousness.

Cite This Article: Dr J G Duresh. (2017). "EFFACING THE TAG OF FUNDAMENTALISM: A READING OF MOSHIN HAMID'S THE RELUCTANT FUNDAMENTALIST." International Journal of Research - Granthaalayah, 5(9:SE), 51-55. https://doi.org/10.5281/zenodo.1004565.

\section{Introduction}

A migrant, in a diasporic context, is constantly haunted by the most perturbing question "Where are you from? and not who/what are you" (Sura P. Rath 8) which in turn heightens or intensifies subjectivity and makes one cling fast on to ethnic or national identity. Gita Viswanath rightly avers, "The constitution of subjectivity is an important theme in post-colonial writings" (180). This subjectivity induces a migrant to augment ethnic/national consciousness, which is well reflected in post-colonial writings. Bill Ashcroft et al affirm that "Post-colonial literatures develop through several stages which can be seen to correspond to stages both of national and regional consciousness ..." (94). Commenting on post-colonial national consciousness, Fanon accepts that "the process of decolonizatioin is a bringing into rhythm of nationalism and national consciousness" (qtd. in Gautam Premnath 65). Moshin Hamid's The Reluctant Fundamentalist is a riveting study of an individual's endeavour for forging ethnic identity and audaciously asserting his attachment towards his country. 
The text of The Reluctant Fundamentalist runs in the form of an utterance in first person in which, Changez, the narrator recaps his tormenting experiences in an alien land and pours them out to an American at a café in Lagore. Changez, a brilliant scholar finishes his Bachelors at Princeton University and joined Underwood Samson, a leading consultancy firm. In a jaunt to Greece with fellow Princetonions, he fosters a serious intimacy with Erica, a bewitching American girl who is still grieving over the death of her childhood sweetheart. Overcoming the initial curbs in their relationship, they become devout lovers with mutual care for each other. However, Erica mysteriously disappears leaving no trace of her identity or any proof of her life.

In Underwood Samson, Changez shoots up to prominence as an intelligent techie which entails him offshore assignments. While he is in Chile on an official obligation, occurs the macabre September 11 attack on America which impels him to stay there for a few more days. On his way back to America, to his great astonishment, at the airport he is segregated from other Americans and interrogated the purpose of his visit and stay in America. Utterly infuriated by the drastic change in America's attitude towards him, the most disconcerting America's attack on Afkhan, the sheer victimization of Muslims and the increasing rift in the relationship between India and Pakistan, Changes quits his promising career and returns to Lahore. As a professor in a university at Lahore, he commits himself to ignite the young Pathan minds to fight against antiPakistan activities. Towards the close of the narration, Changez and the American near the hotel when the stranger reaches into his pocket which is evident from the glint of metal. Whether he has taken a visiting card as a token of intimacy or a gun as he is offended by the harangue of Changez, is left to the fancy of the readers.

Hamid's The Reluctant Fundamentalist with photographic fidelity, depicts the intensification of the atavistic urge and steep escalation of ethnic and national consciousness of Changez following the September 11 attack. What looms large and calls the attention of an avid reader of the novel is the springing up of primordial urge that lies hidden in a migrant's psyche and the rapid twist in the outlook of a migrant towards the adopted country which are vindicative of the fact that a migrant is moored to his native land and culture despite his sojourn in the new land and acculturation. With this heightened sense of ethnic consciousness, Changez perceives events. Curious enough, Changez, the narrator/protagonist is none other than the author himself. Exactly like Changez, Hamid attended Princeton University and worked as a management consultant. The only deviation is, Hamid lives in London but as his wish fulfillment he makes his protege Changez return to Lahore and kindle young minds to fight for native land.

Hamid's excessive love for his nation and race makes him look deep into the despicable plights of the community. Down in memory lane, he recounts the past of Pakistan which was invaded by the Aryans to the Britishers, which in fact is one of the foremost reasons for the country's backwardness. When Changez attends an interview in Underwood Samson, he is asked about his nationality he replies: “. . . I was from Lahore, the second largest city in Pakistan, ancient capital of the Punjab, home to nearby as many people as New York, layered like a sedimentary plain with the accreted history of invaders from the Aryans to the Mongals to the British" (Hamid 7).

As power being the base of technological advancements, Hamid reckons the frequent blackouts in Pakistan as a severe hindrance to progress. Though there is no provocation to refer to this, Changez compares Pakistan and America and in a tone of regret he reports, ". . . we face a 
shortage of electricity that manifests itself in rolling blackouts. We call this load-shedding . .." (47).

Delving deep into the debilitating entanglements of Pakistan, Hamid phathoms out the causes for the present maladies of the country. In a chat between Changez and Erica's father, the later sums up the state of affairs in the country. "Economy's falling apart though, no? Corruption, dictatorship, the rich living like princes while everyone else suffers. Solid people, don't get me wrong. I like Pakistanis. But the elite has raped that place well and good, right? And fundamentalism" (55).

Cast down by the precarious present of his country, Hamid draws a little consolation in the splendid performance of the Pakistani's cricket team. Likewise, he holds aloft the food habits of his country. "Perhaps because we currently lack wealth, power, or even sporting glory - the occasional brilliance of our temperamental cricket team notwithstanding - commensurate most popular country, we Pakistanis tend to take an inordinate pride in our food . .." (101). In a similar vein Hamid draws a pragmatic comparison between Pakistan and America with regard to the ancientness and gloats over that glorious past of his country with a highly developed civilization.

Four thousand years ago, we, the people of the Indus river basin, had cities that were laid out on grids and boasted underground sewers, while the ancestors of those who would invade and colonize America were illiterate barbarians. Now our cities were largely preplanned unsanitary affairs, and America had universities with individual endowments greater than our national budget for education. (14)

In his tirade against America, Hamid exults in the past glory of Pakistan. Changez succinctly points out that America was just a collection of thirteen colonies when Pakistan excelled in art and architecture. "We built the Royal Mosque and the Shalimar Gardens in this city, and we built the Lahore Fort with its mighty walls and wide ramp for our battle-elephants. And we did these things when your country was still a collection of thirteen small colonies, gnawing away at the edge of a continent" (102).

Despite Changez' education and employment in America, a sort of animosity towards the country smoulders in him. While watching the attack of World Trade Centre in TV, he experienced a kind of inward joy. He avers, "I stared, as one and then the other of the twin towers of New York's World Trade Centre collapsed. And then I smiled, Yes despicable as it may sound, my initial reaction was to be remarkably pleased" (72). Changez' racial consciousness razed essential human values and consequently instead of feeling pity for the hapless victims, he feels elated as someone has put America to shame. ". . . I was caught up in the symbolism of it all, the fact that someone had so visibly brought America to her knees" (75).

Changez' racial consciousness and excessive concern for his country come to the fore in his response to the plights of his countrymen. He always unveils a callous non-chalant attitude towards the victimized Americans and becomes nervous and panoroic over the attack of his countrymen and a very thought of a war between India and Pakistan. He is much disheartened over the attack on Pakistanis, desecration of mosques and the crude interrogation of Muslims. 
His excessive solicitude for his country makes him wish and pray that the incidents he hears should be imaginary and unreal. "I respond that these stories were mostly untrue . . ." (94). Similarly, Chengez does not have the nerve to listen to news bulletins about the attack on Afghanistan by America. His racial and ethnic consciousness reaches its height on his observation of America attacking Afghanistan.

.. I I chanced upon a new cart with ghostly night vision images of American troops dropping into Afghanistan for what was described as a daring raid on a Taliban command port. My reaction caught me by surprise; Afghanistan was Pakistani's neighbor, our friend, and a fellow Muslim nation besides, and the sight of what I took to be the beginning of its invasion by your countrymen caused me to tremble with fury. (100)

Changez who is hyper sensitive to the threats to his country is not at all bothered about the terrorist attack on Indian Parliament. His sole concern is for his country and brooding over the possibilities of war between India and Pakistan. He even ignores celebrating his professional achievement and is thinking of his country. "I should have been ecstatic, but earlier that weak armed men had assaulted the Indian Parliament, and instead of celebrating my good fortune, I was confronting the possibility that soon my country could be at war" (120). In a state of illusion, he hears the "sound of military helicopters flying low overhead" and he even imagines "soon traffic would be halted so that our fighter planes could practice landing on it ..." (127). Overwhelmed by relentless affection and involvement for his country he yells that in case of a war between India and Pakistan, America should come to the rescue of Pakistan. He even dreams that "all America would have to do would be to inform India that an attack on Pakistan would be treated as an attack on any American ally and would be responded to by the overwhelming force of America's military" (143).

A studious reading of the novel will drive home that the ultimate objective of Hamid is to remove the tag of terrorism, fundamentalism and backwardness attached to his country. It is a consorted effort on the part of the novelist to declare that Pakistan is not as bad a country reported in the media and the Pathans are not at all terrorists. In a casual talk, Erica's father pinpoints to Changez the social issues including fundamentalism in Pakistan. In order to save the image of his country, Changez replies, "Yes there are challenges, Sir, but my family is there, and I can assure you it is not as bad as that" (55). Similarly, towards the close of the novel, Changez implores the stranger who can be construed as the representative of international community that "you should not imagine that we Pakistanis are all potential terrorists" (183).

\section{References}

[1] Bill Ashcroft, Gareth Griffiths and Helen Tiffin. "Introduction." The Empire Writes Back. London: Routledge 2002. 1-13. Print.

[2] Gita Viswanath. "Post-colonialism and the Discourse of Marginality". Journal of Contemporary Thought (Summer 1999): 175 - 184. Print.

[3] Golden, S. A. R. (2016). Rural Students' attitude towards English as Medium of Instruction In Higher Education-An Analysis. International Journal of Research, 3, 1-10.

[4] Golden, S. A. R. (2017). Attitude of Students and Teachers towards E-Learning-An Analysis. Recent Research in Social Science \& Humanities, 1, 5-10. 
[5] Golden, S. A. R. (2017). Recent Research in Social Sciences \& Humanities. EduPedia Publications (P) Ltd.

[6] Hamid, Mohsin. The Reluctant Fundamentalist. Delhi: Penguin, 2007. Print.

[7] Premnath, Gautam, "Remembering Fanon, Decolonizing Diaspore". Postcolonial Theory and Criticism. Ed. Laura Chrisman and Benita Parry. Cambridge: D.S. Brewer, 2000, 57-74. Print.

[8] Rath, Sura P. "Home(s) Abroad: Diasporic Identities in Third Spaces." Journal of Contemporary Thought (Summer 1999): 7 - 23. Print. 